\title{
DNA Barcoding of Fungi in the Forest Ecosystem of the Psunj and Papuk Mountains in Croatia
}

\author{
Nevenka Ćelepirović ${ }^{1, *}$, Sanja Novak Agbaba², Monika Karija Vlahović ${ }^{3}$
}

(1) Croatian Forest Research Institute, Division of Genetics, Forest Tree Breeding and Seed Science, Cvjetno naselje 41, HR-10450 Jastrebarsko, Croatia; (2) Croatian Forest Research Institute, Division of Forest Protection and Game Management, Cvjetno naselje 41, HR-10450 Jastrebarsko; (3) University of Zagreb, School of Medicine, Department of forensic medicine and criminology, DNA Laboratory, HR-10000 Zagreb, Croatia.

* Correspondence: e-mail: nevenkac@sumins.hr
Citation: Ćelepirović N, Novak Agbaba S, Karija Vlahović M, 2020. DNA Barcoding of Fungi in the Forest Ecosystem of the Psunj and Papuk Mountains in Croatia. South-east Eur for 11(2): early view. https://doi.org/10.15177/seefor.20-17.

Received: 21 Jul 2020; Revised: 10 Nov 2020; Accepted: 18 Nov 2020; Published online: 7 Dec 2020

\begin{abstract}
The saprotrophic, endophytic, and parasitic fungi were detected from the samples collected in the forest of the management unit East Psunj and Papuk Nature Park in Croatia. The disease symptoms, the morphology of fruiting bodies and fungal culture, and DNA barcoding were combined for determining the fungi at the genus or species level. DNA barcoding is a standardized and automated identification of species based on recognition of highly variable DNA sequences. DNA barcoding has a wide application in the diagnostic purpose of fungi in biological specimens. DNA samples for DNA barcoding were isolated from infected tree tissues, fungal fruiting bodies or fungal cultures. The ITS or ITS2 sequences of the fungal DNA were sequenced and aligned with the reference sequences in GenBank (NCBI) using BLAST. The size of ITS and ITS2 sequences were 512-584 bp and 248-326 bp, respectively. The sequences showed a high identity of $97.21 \%-100 \%$ at $98 \%-100 \%$ coverage with reference sequences in GenBank (NCBI). The exception was the species Amphilogia gyrosa that showed $95.65 \%$ identity at $100 \%$ coverage. Two fungi were determined at genus level: Cladosporium sp., and Cytospora sp., while 11 fungi were determined at species level: Alternaria alternata, Aureobasidium pullulans, Amphilogia gyrosa, Capronia pilosella, Cryphonectria parasitica, Exidia glandulosa, Epicoccum nigrum, Penicillium glabrum, Pezicula carpinea, Rosellinia corticium, and Stereum hirsutum.
\end{abstract}

Keywords: GenBank; BLAST; Fagus sylvatica; Ascomycota; Basidiomycota; DNA sequencing

\section{INTRODUCTION}

DNA barcoding is a standardized and automated biological specimen identification system (Casiraghi et al. 2010). A DNA barcode is a relatively short gene sequence of the highly variable sequences of the genome, unique for the identification of species. The advantage of this technique is that a single specimen can provide complete information about the species, regardless of the morphology or lifestage characteristics. Hebert et al. (2003) recognized that the mitochondrial enzyme cytochrome $c$ oxidase subunit 1 coding DNA could be applied to generate DNA barcode in animals. Over time, the procedure has been applied to flora and fungi. At present, DNA barcoding can be regarded as a method that is acceptable for all live tree branches. Further research into the genome of organisms revealed that for certain groups of organisms, different sequences of the genome are more acceptable for DNA barcoding. The most commonly used sequence for queries of systematics and taxonomy at and below the genus level for fungi is the internal transcribed spacer (ITS) sequence of the nuclear ribosomal repeat unit (Nilsson et al. 2009, Seifert 2009, Schoch et al. 2011, Xu 2016, Badotti et al. 2017). Easy amplification, common usage, and sufficient barcode distance of ITS sequence are characteristics that allow a wide application as a barcode for fungi (Raja 2017). ITS sequence consists of ITS1 and ITS2 sequences surrounding the 5.8S ribosomal RNA sequence (White et al. 1990, Martin et al. 2005). Blaalid et al. (2013) reported that the ITS1 sequences showed more variable characteristics than the ITS2 sequences, including changes in length and GC content and polymorphism. Nevertheless, research by Yang et al. (2018) proved that the operational taxonomic richness and details of the fungal community in the ITS2 sequence concerning the full-length ITS sequence produced similar results.

In recent years, information about the nucleotide sequences was deposited in public databases of European Nucleotide Archive (ENA) at the European Bioinformatics Institute (EBI) established in 1982; the DNA Data Bank of Japan 
(DDBJ) of the National Institute of Genetics (NIG) established in 1987 and GenBank at the National Center for Biotechnology Information (NCBI) established in 1988. Their cooperation in the mind of the International Nucleotide Sequence Database Collaboration (INSDC) and the product database from this framework is called the International Nucleotide Sequence Database (INSD) (Amid 2020). The GenBank is constantly updated with new DNA sequences. A unique accession number is assigned to each newly uploaded DNA sequence. A bioinformatics accession number is a specific ID that may be used to identify various releases of this sequence record and the related sequences in similar repositories over time. DNA barcoding is based on the assumption that the unknown DNA sequence can clearly be defined if it is compared with a reference sequence in a database. The similarity determination process is reliable and fast using algorithms specially developed for this purpose. The commonly used algorithm is the Basic Local Alignment Search Tool (BLAST, NCBI). The key functions of the public databases are to establish a credible source for fungal diagnostics, allowing accurate detection of the causative agents of fungal infections, timely evaluation of mycoses, and early initiation of effective protection measures.

Many saprotrophic, entophytic, and parasitic fungal species evolved as members of complex communities with their host by its capacity to cause tree death, defoliation, decay, or deformation (Unterseher et al. 2010). Among these species, some of them gained significant ecological value as agents of disruption, playing a role in the regulation of forest characteristics. Fungal species communicate, explicitly and indirectly, with other ecological group members, impacting specific environmental processes, foodstuffs, and habitat formation for other organisms (Naranjo-Ortiz and Gabaldón 2019). The endophytes may change their lifestyle and become parasite or saprotroph (Sieber et al. 1987, Sinclair et al. 1996, Stone et al. 2000, Promputtha et al. 2007). The saprotrophs may become a threat to the tree, becoming parasites in special circumstances, and attacking living tissues of the host species, causing death (Prell and Day 2001).

The Papuk and Psunj mountains are part of the Slavonian Mountains located on the southern edge of the Pannonian plain. The largest part of the forest cover in these areas consists of Fagus sylvatica stands (Škvorc et al. 2011). According to the information on the web page of Papuk Nature Park (https:// pp-papuk.hr), more than 100 fungal species were determined that have been established in this area. However, it is not the final number due to insufficient research. So far, the scientific research of fungi on forest trees in the forest area of the Papuk and Psunj mountains using DNA barcoding has not been conducted. This research was intended to determine specimens of forest saprotrophic, entophytic, and parasitic fungi in the management unit East Psunj and Papuk Nature Park. Determination of specimens collected on the basis of disease symptoms, the presence of fruiting bodies, fungal culture morphology, and DNA barcoding techniques was performed. The purpose of this research was to supplement the DNA databases with new fungal sequences. Collecting sequences in the database allows complement barcode library of the European fungal taxa, thereby intensifying DNA barcode reference libraries relevant to European countries.

\section{MATERIALS AND METHODS}

\section{Sample Collection}

The first set of samples was collected in the area of management unit East Psunj (45.42 N, 17.48 E), Forest office Požega, Forest Administration Požega, Croatian Forests Ltd. The second set of samples was collected in the area of Campsite Duboka in Papuk Nature Park (45.47 N, 17.65 E), in a northeast direction around $6 \mathrm{~km}$ from the camp. Different types of tree samples were collected: tree branches and bark samples with disease symptoms, and fungal fruiting structures. The collection points were georeferenced with the Global Positioning System. The plant or fungal material was properly determined, dated, packed in plastic bags, and transported to the laboratory.

\section{Detection of Disease Symptoms, Fungal Fruiting Bodies and Culture Morphology}

The disease symptoms on the samples were recorded and the causal agents of disease were determined according to the description in the literature (Sinclair and Dhingra 1995, Hanlin 1990). The morphological characteristics of the fungal fruiting bodies were analysed macroscopically and using a stereo zoom Lupa Olympus SZH and Olympus BX2 light microscope. The fungal samples on wood materials were stored in the fungal collection. For fungi isolation, small parts of plant material $(5 \mathrm{~mm}$ ) showing symptoms were sterilized for 3 min with $70 \%$ ethanol, rinsed in autoclaved distilled water and placed on a filter paper to remove excess liquid. The pieces were aseptically placed on sterile potato dextrose agar (PDA) medium in Petri dishes and incubated for 7-10 days at room temperature $\left(21\right.$ to $\left.25^{\circ} \mathrm{C}\right)$ under ambient light. Fungal cultures were stored at $4^{\circ} \mathrm{C}$. The morphological determination was based on the data from the Electronic Atlas of the Flora of British Columbia (E-Flora BC, 2013), Encyclopedia of Life (https://eol.org/), Zubrik et al. 2008. The taxonomy was stated according to Index Fungorum (www.indexfungorum.org).

\section{DNA Extraction, Amplification, Sequencing and Species Determination}

For DNA extraction, part of the plant material showing symptoms, part of fruiting bodies, or the piece of fungal culture was collected in Eppendorf tubes. DNA was extracted from $0.1 \mathrm{~g}$ of plant material according to the protocol described in the QIAamp DNA Stool Mini Kit (Qiagen, Germany), or from the fungal fruiting body according to the CTAB method (Doyle and Doyle, 1987) using $2 \%$ cetyl trimethyl ammonium bromide (CTAB) buffer supplemented with $1 \%$ (wt/vol) of polyvinylpyrrolidone (PVP). DNA was resuspended in $50 \mu \mathrm{l}$ of ultrapure water. The quality and quantity of DNA were checked by electrophoresis in $1 \mathrm{x}$ TBE buffer, $\mathrm{pH} 8.0$ using $0.8 \%$ agarose gel stained with GelStar Nucleic Acid Gel Stain dye (Lonza Rockland, Inc., Rockland, USA). Lambda DNA/Hind III fragment (Invitrogen, Germany) was used as a DNA marker and the DNA concentration was measured by spectrophotometry (Biospec-nano, Shimadzu). The obtained DNA in the extracts ranged from 9.64 to $269.98 \mathrm{ng} / \mu \mathrm{l}$. The ITS (ITS1-5.8S-ITS2) sequences were obtained by amplification using universal pairs of primers ITS1-ITS2 and ITS3-ITS4. 
PCR amplification was performed in a final volume of $20 \mu \mathrm{l}$ containing 1x PCR buffer, $0.8 \mathrm{mg} / \mathrm{ml}$ BSA (Bovine Serum Albumin, Amersham Pharmacia Biotech, USA), $0.5 \mu \mathrm{M}$ of each primer, 1 unit of TaKaRa Taq DNA Polymerase (Takara, Japan) and $0.6 \mathrm{ng}$ of template DNA. Amplification cycle parameters using ITS1-ITS2 primers were as follows: initial denaturation $94^{\circ} \mathrm{C}$ for $5 \mathrm{~min}, 30$ cycles of $95^{\circ} \mathrm{C}$ for $1 \mathrm{~min}, 59^{\circ} \mathrm{C}$ for $1 \mathrm{~min}$ and $72^{\circ} \mathrm{C}$ for $1 \mathrm{~min}$, and then the final cycle $72^{\circ} \mathrm{C}$ for $10 \mathrm{~min}$. Amplification cycle parameters using ITS3-ITS4 primers were as follows: initial denaturation $94^{\circ} \mathrm{C}$ for $5 \mathrm{~min}$, and 30 cycles of $95^{\circ} \mathrm{C}$ for $1 \mathrm{~min}, 56^{\circ} \mathrm{C}$ for $1 \mathrm{~min}$ and $72^{\circ} \mathrm{C}$ for $1 \mathrm{~min}$, and then the final cycle $72^{\circ} \mathrm{C}$ for $10 \mathrm{~min}$. All PCR reactions were performed along with negative control containing ultrapure water instead of DNA and in-house positive control containing DNA extracted from fungi Eutypella parasitica (Novak Agbaba et al. 2015). The amplification of DNA fragments was performed on a PTC-100 thermocycler (MJ Research, USA). All PCR products were separated by electrophoresis on $1.8 \%$ agarose gel in $1 x$ TBE buffer pH 8.0 stained with GelStar Nucleic Acid Gel Stain, (Lonza Rockland, Inc., Rockland, USA). A DNA marker Tracklt $1 \mathrm{~kb}$ Plus DNA Ladder (Invitrogen, Germany) was used as a molecular weight marker, and the gel was photographed under UV light (UVtec Cambridge, UK). Amplified DNA was purified from the $1.8 \%$ agarose gel using the PureLink Quick Gel Extraction Kit (Invitrogen, Germany). PCR products were sequenced in both forward and reverse directions using ITS1/ITS2 primer pair and ITS3/ITS4 primer pair. Sequences were analyzed and reviewed using DNA Sequencing Analysis Software v6.0 (Applied Biosystems, Foster City, CA, USA). The consensus ITS sequences were assembled using SeqScape ${ }^{\circledR}$ software v3 (Applied Biosystems, Foster City, CA, USA). The consensus ITS or ITS2 sequence identification was performed using BLAST (Basic Local Alignment Search Tool) (Madden, 2013). According to the suggestion by the authors (Brock et al. 2009 , Raja et al. 2017), minimum $\geq 80 \%$ query coverage, and $\geq 97 \%$ cut-off for species recognition was applied. When more than one species was determined inside the cut-off ranges, the classification of the first highest-identity species that appeared in the BLAST report was chosen. Once the fungal species were determined, the DNA sequences were submitted to GenBank (NCBI, Bethesda, MD, USA).

\section{RESULTS}

The identification of fungal species was performed by combining the disease symptoms, the morphology of fruiting bodies, culture morphology, and DNA barcoding of the samples collected in the forest of the management unit East Psunj and Papuk Nature Park, (Tables 1 and 2, respectively).

On the site of management unit East Psunj, fungi were determined from three twig samples of Fagus sylvatica, two bark samples of Castanea sativa, and two fungal fruiting bodies on the branch of F. sylvatica. On F. sylvatica, five fungal species were determined on a single twig with necrosis (Table 1). Two strains were determined at $C$. parasitica, hypovirulent, and virulent. In total, nine species of fungi were determined on the site of management unit East Psunj on F. silvatica and C. sativa samples.

Alternaria alternata (Fr.) Keissl. (Ascomycota) is an endophyte and a parasite. In our sample, A. alternate was determined as endophyte on a twig (Table 1). It was isolated by culturing the necrotic twig tissue. DNA was isolated from grey-brownish fungal culture. The ITS sequence of $567 \mathrm{bp}$ in $100 \%$ identity at $100 \%$ coverage corresponded to reference sequence $A$. alternata (GenBank accession number MN481948.1).

Aureobasidium pullulans (de Bary \& Löwenthal) G. Arnaud (Ascomycota) is a saprotroph and an endophyte that lives on decaying twig and leaves. In our sample, $A$. pullulans was determined as endophyte on a twig (Table 1). It was isolated by culturing the necrotic twig tissue. DNA was isolated from cream-colored fungal culture. The ITS sequence of 515 bp in $100 \%$ identity at $100 \%$ coverage corresponded to reference sequence $A$. pullulans (GenBank accession number MT573468.1).

Cladosporium sp. Link (Ascomycota) is a saprotroph, a parasite, and an endophyte. In our sample, Cladosporium sp. was determined as endophyte on a twig (Table 1). It was isolated by culturing the necrotic twig tissue. DNA was isolated from olivaceous-green fungal culture (Figure $1 \mathrm{~g}$ ). The ITS sequence of 552 bp in $100 \%$ identity at $100 \%$ coverage corresponded to reference sequences in descending order as follows: Cladosporium pseudocladosporioides (GenBank accession number MT582794.1), Cladosporium cladosporioides (GenBank accession number MT466517.1), and Cladosporium sp. (GenBank accession number MK355726.1). However, the morphological characteristics of the fungal PDA culture were insufficient for species determination. Based on the data from the BLAST report, the fungus was determined on the genus level as Cladosporium sp. (Figure 1g).

Cryphonectria parasitica (Murrill) M.E. Barr (hypovirulent) (Ascomycota) is a parasite and a saprotroph. In our sample, C. parasitica was determined as a parasite. It was isolated from superficial bark canker (Heiniger et al. 1994, Robin et al. 2001) by culturing the infected bark (Table 1, Figure 1a). DNA was isolated from white fungal culture (Figure 1f). The ITS2 sequence of 326 bp in $99.69 \%$ identity at $99 \%$ coverage corresponded to reference sequence $C$. parasitica (GenBank accession number KP824756.1). Cryphonectria parasitica (Murrill) M.E. Barr (virulent) was isolated from active bark canker (EPPO 2005) by culturing the infected bark (Table 1 , Figure 1b). DNA was isolated from orange fungal culture (Figure 1f). The ITS2 sequence of 248 bp in $99.60 \%$ identity at $100 \%$ coverage corresponded to reference sequence $C$. parasitica (GenBank accession number MT256127.1).

Cytospora sp. Ehrenb. (Ascomycota) is a parasite, a saprotroph, and an endophyte. In our sample, Cytospora sp. was determined as a parasite that causes drying of branches and twigs from the tips and leaves becoming brown and dry (Table 1). It forms cankers and necrosis under the bark. It was isolated from the bark canker by culturing the infected wood. DNA was isolated from dark brown fungal culture. In the BLAST report, the ITS sequence of $584 \mathrm{bp}$ corresponded to reference sequences in descending order as follows: Cytospora ribis $199.31 \%$ identity at $99 \%$ coverage, GenBank accession number KU058681.1), C. ribis (99.14\% identity at 99\% coverage, GenBank accession number KU165798.1), Cytospora rhodophila $(99.14 \%$ identity at $99 \%$ coverage, GenBank accession number KF294010.1) and Cytospora prunicola $(99.48 \%$ identity at $98 \%$ coverage, GenBank accession number NR157500.1), C. ribis $(98.97 \%$ identity at 
99\% coverage, GenBank accession number KU170615.1), C. ribis $(98.80 \%$ identity at $99 \%$ coverage, GenBank accession number KU170616.1), Cytospora sp. (99.13\% identity at 98\% coverage, GenBank accession number MT177936.1). However, the morphological characteristics of the fungal PDA culture were insufficient for species determination. Based on the data from the BLAST report, the fungus was determined at the level of the genus as Cytospora sp.

Epicoccum nigrum Link (Ascomycota) is a saprotroph, an endophyte, and a parasite that causes necrosis under bark and causes drying of twigs and branches. In our sample, the fungus was determined as an endophyte on a twig (Table 1). It was isolated by culturing the necrotic twig tissue. DNA was isolated from pink fungal culture (Figure 1h). ITS sequence of $544 \mathrm{bp}$ corresponded to reference sequence $E$. nigrum (100\% identity at $100 \%$ coverage, GenBank accession number AB470853.1).

Exidia glandulosa (Bull.) Fr. (Basidiomycota) is a saprotroph. In our research, it was determined on the tree of $F$. sylvatica forming branch, black, jelly fruiting bodies causing decay (Table 1, Figure 1c). The fungus detection was done according to the morphological characteristics of the fruiting body. DNA was isolated from the fruiting body. The ITS sequence of 577 bp in 100\% identity at $99.31 \%$ coverage corresponded to reference sequence $E$. glandulosa (GenBank accession number MF161201.1).

Penicillium glabrum (Wehmer) Westling (Ascomycota) is a parasite and an endophyte. In our sample, $P$. glabrum was determined as an endophyte on a twig (Table 1). It was isolated by culturing the necrotic twig tissue. DNA was isolated from green fungal culture. The ITS sequence of $578 \mathrm{bp}$ in $100 \%$ identity at $100 \%$ coverage corresponded to reference sequence $P$. glabrum (GenBank accession number MK910045.1).

Stereum hirsutum (Willd.) Pers. (Basidiomycota) is a saprotroph and a parasite. It causes decay of the trunk. In our sample, $S$. hirsutum was determined as a saprotroph. It was determined on a tree of $F$. sylvatica forming orange shelf-fruiting bodies on the bark (Table 1, Figure 1d). The fungus detection was done according to the morphological characteristics of the fruiting body. DNA was isolated from the fruiting body. The ITS sequence of 577 bp in $99.41 \%$ identity at $100 \%$ coverage corresponded to reference sequence $S$. hirsutum (GenBank accession number KR909200.1).

On the site of Papuk Nature Park, fungi on four samples of semi-dry branches of $F$. sylvatica, and one fungal fruiting body were determined on the bark of $C$. avellana and $F$. sylvatica each. On the single tree of $F$. sylvatica, five species of the fungi were determined on a semi-dry branch with necrosis (Table 2).

Amphilogia gyrosa (Berk. \& Broome) Gryzenh., H.F. Glen \& M.J. Wingf. (Ascomycota) is a parasite. It was determined according to the symptoms on the branch (orange to brawn necrosis) (Table 2). DNA was isolated from the sawdust from infected wood. The ITS2 sequence of $319 \mathrm{bp}$ in $95.65 \%$ identity at $100 \%$ coverage corresponded to reference sequence A. gyrosa (GenBank accession number EF026147.1). Even though the fact that the sequence identity with the GenBank sequences was under $97 \%$, the symptoms of the disease on the branch strongly support the identification of the fungus as $A$. gyriosa.

Capronia pilosella (P. Karst.) E. Müll., Petrini, P.J. Fisher, Samuels \& Rossman (Ascomycota) is a saprotroph on the decay branch. The fruiting body of the fungus is dark brown to black (Table 2). C. pilosella on the branch of $C$. avellana was found (Table 2). The fungus detection was done according to the morphological characteristics of the fruiting body. DNA was isolated from the fruiting body. The ITS2 sequence of $319 \mathrm{bp}$ in $97.2 \%$ identity at $98 \%$ coverage corresponded to reference sequence $C$. pilosella (GenBank accession number DQ826737.1).

Epicoccum nigrum Link. (Ascomycota) is a pathogen, an endophyte, and a saprotroph. In our sample, it is endophyte inside the branch of $F$. sylvatica (Table 2). It was isolated by culturing the necrotic branch tissue. DNA was isolated from pink fungal culture. The ITS sequence of $515 \mathrm{bp}$ corresponded

Table 1. Data of the samples collected on the site of management unit East Psunj.

\begin{tabular}{|c|c|c|c|c|c|}
\hline No & $\begin{array}{l}\text { Fungal } \\
\text { species }\end{array}$ & Host tree species & $\begin{array}{l}\text { Locality } \\
(\mathrm{N}, \mathrm{E})\end{array}$ & Sample of plant tissue & $\begin{array}{c}\text { GenBank Accession } \\
\text { number (NCBI) }\end{array}$ \\
\hline 1 & Alternaria alternata & Fagus sylvatica & $\begin{array}{l}45.4207 \\
17.4816\end{array}$ & Twig with necrosis & MN251032.1 \\
\hline 3 & Cladosporium sp. & Fagus sylvatica & $\begin{array}{l}45.4207 \\
17.4816\end{array}$ & Twig with necrosis & MN251034.1 \\
\hline 4 & Cryphonectria parasitica & Castanea sativa & $\begin{array}{l}45.4219 \\
17.4805\end{array}$ & $\begin{array}{c}\text { Bark with symptoms of } \\
\text { superficial canker (hypovirulent) }\end{array}$ & MN251044.1 \\
\hline 5 & Cryphonectria parasitica & Castanea sativa & $\begin{array}{l}45.4231 \\
17.4803\end{array}$ & $\begin{array}{l}\text { Bark canker, fan-shaped } \\
\text { mycelium under the bark }\end{array}$ & MN251045.1 \\
\hline 6 & Cytospora sp. & Fagus sylvatica & $\begin{array}{l}45.4207 \\
17.4816\end{array}$ & Twig with necrosis & MN251035.1 \\
\hline 7 & Epicoccum nigrum & Fagus sylvatica & $\begin{array}{l}45.4207 \\
17.4816\end{array}$ & Twig with necrosis & MN251033.1 \\
\hline 9 & Penicillium glabrum & Fagus sylvatica & $\begin{array}{l}45.4207 \\
17.4816\end{array}$ & Twig with necrosis & MN251036.1 \\
\hline 10 & Stereum hirsutum & Fagus sylvatica & $\begin{array}{l}45.4236 \\
17.4803\end{array}$ & $\begin{array}{c}\text { Orange shelf fruiting bodies } \\
\text { on bark }\end{array}$ & MN251029.1 \\
\hline
\end{tabular}


to reference sequences in descending order as follows: Epicoccum layuense (99\% identity, 100\% coverage GenBank accession number MT573479.1), and E. nigrum (99\% identity, 100\% coverage, GenBank accession number MK793731.1). However, based on the morphological characteristics of the fungal PDA culture, the fungus was determined as $E$. nigrum.

Pezicula carpinea (Pers.) Tul. ex Fuckel (Ascomycota) is a parasite, a saprotroph, and an endophyte. The branch with canker wounds was collected (Table 2). In our sample, the fungus was determined as a parasite. DNA was isolated from the infected branch's bark. The ITS sequence of 516 bp corresponded to reference sequence $P$. carpinea (100\% identity, $100 \%$ coverage, GenBank accession number NR_144927.1).

Rosellinia corticum (Schwein) Sacc. (Ascomycota) is a saprotroph and an endophyte. In our sample, it was determined as a saprotroph on the tree of $F$. sylvatica, forming black fruiting bodies that cause semi-dray necrosis on the branch (Table 2). The fungus detection was done according to the morphological characteristics of the fruiting body. DNA was isolated from the fruiting body. The ITS sequence of 562 bp in $99.28 \%$ identity at $98 \%$ coverage corresponded to reference sequences $R$. corticum (GenBank accession number KC311485.1).

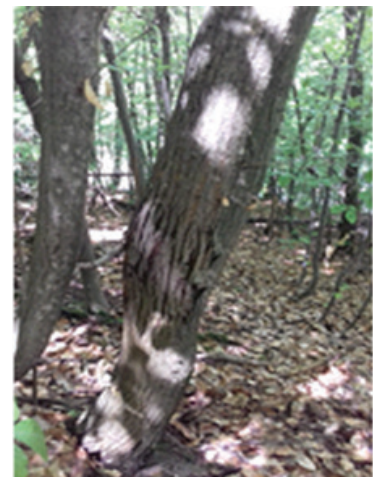

a

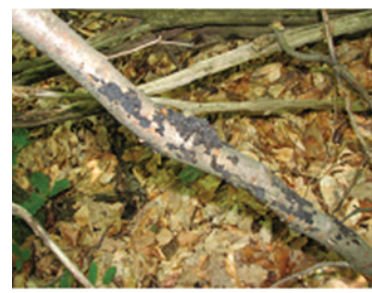

C

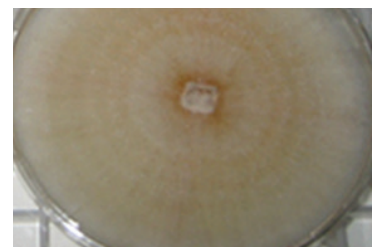

e

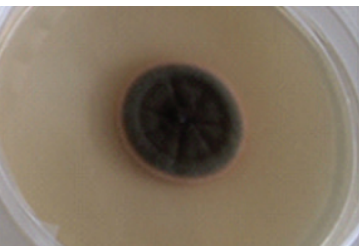

g

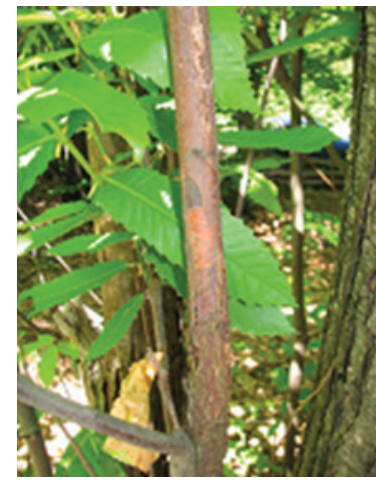

b
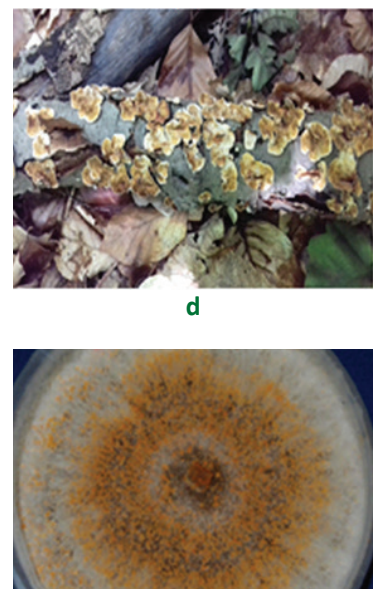

f

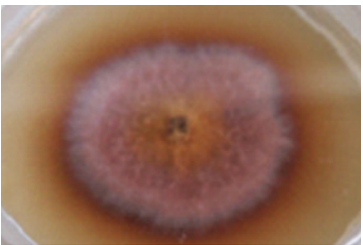

h

Figure 1. Disease symptoms and fruiting bodies on trees and fungal culture from the site of management unit East Psunj. (a) Superficial canker on C. sativa; (b) Active canker on C. sativa; (c) S. hirsutum on the bark of F. sylvatica; (d) Exidia glandulos on F. sylvatica; (e) Culture of $C$. parasitica (hypovirulent); (f) Culture of C. parasitica (virulent); (g) Culture of Cladosporium sp.; (h) Culture of Epicoccum nigrum. 
Table 2. Data of the samples collected in Papuk Nature Park.

\begin{tabular}{|c|c|c|c|c|c|}
\hline No & $\begin{array}{l}\text { Fungal } \\
\text { species }\end{array}$ & Host tree species & $\begin{array}{l}\text { Locality } \\
\text { (N, E) }\end{array}$ & Sample of plant tissue & $\begin{array}{c}\text { GenBank Accession } \\
\text { number (NCBI) }\end{array}$ \\
\hline 1 & $\begin{array}{l}\text { Amphilogia } \\
\text { gyrosa }\end{array}$ & Fagus sylvatica & $\begin{array}{l}45.4875 \\
17.6801\end{array}$ & Semi-dry top of branch & MN251039.1 \\
\hline 2 & $\begin{array}{l}\text { Capronia } \\
\text { pilosella }\end{array}$ & Corylus avellana & $\begin{array}{l}45.4741 \\
17.6577\end{array}$ & $\begin{array}{l}\text { Black fruiting bodies on } \\
\text { semi-rotten branch }\end{array}$ & MN251043.1 \\
\hline 3 & $\begin{array}{l}\text { Epicoccum } \\
\text { nigrum }\end{array}$ & Fagus sylvatica & $\begin{array}{l}45.4877 \\
17.6812\end{array}$ & Necrosis on semi-dry branch & MN251030.1 \\
\hline 4 & $\begin{array}{l}\text { Pezicula } \\
\text { carpinea }\end{array}$ & Fagus sylvatica & $\begin{array}{l}45.4875 \\
17.6800\end{array}$ & $\begin{array}{l}\text { Branch with canker } \\
\text { symptoms }\end{array}$ & MN251038.1 \\
\hline 5 & $\begin{array}{l}\text { Rosellinia } \\
\text { corticum }\end{array}$ & Fagus sylvatica & $\begin{array}{l}45.4877 \\
17.6812\end{array}$ & $\begin{array}{l}\text { Black fruiting bodies on the } \\
\text { branch }\end{array}$ & MN251031.1 \\
\hline
\end{tabular}

\section{DISCUSSION}

The symptoms of infected forest plant tissues can identify the fungi causing plant diseases. The necrosis on the twig, bark blight, discoloration of the bark, and fruiting bodies were registered as symptoms on the assessed trees. Identifying any fungus species that cause a disease is a complex procedure because many of them cause similar symptoms (Butun, 1995). The culture-dependent approaches based on the morphological detection of fungal identification have restrictions such as the slow growth rate of fungi, contamination with competitive fungi, or identical appearance of the culture, excluding biotrophic and slow-growing fungi and promoting fast-growing fungi (Shi et al. 2019). DNA barcoding is a new effort to get quick and accurate recognition of organisms (Hebert and Gregory, 2005). However, research by Hofstetter et al. (2019) regarding the species of fungi in protected Montricher Beech Forest (Switzerland) using BLAST identification tools reported that the number of ITS sequences related to the incorrect taxon name tends to be approximately $30 \%$. Considering the fact of mistaken species identification using ITS sequence, Ciat et al. (2006) propose a three-step method for a diagnostic procedure that incorporates morphological parameters, biochemical study, and ITS sequence analysis.

In this work, 13 fungal species were determined, out of which there was the same number of saprotrophs and parasites (four species of each) and five endophytes. The samples were collected from three tree species $F$. sylvatica, $C$. sativa and $C$. avellana. The most fungal species were determined on F. sylvatica, 11 fungal species, whereas on $C$. sativa and $C$. avellana one fungal species was determined per tree species (Tables 1 and 2). The five fungi were determined on one branch of $F$. sylvatica. Four of them were endophytes (A. alternata, A. pullulans, Cladosporium sp, and E. nigrum) and one was parasite (Cytospora sp.). On the other F. sylvatica tree, two fungi were determined, E. nigrum and $R$. corticum. Only one of the fungal species, E. nigrum, was determined on both localities. In our work, DNA barcoding was performed from different types of tissues: tree tissue with disease symptoms, fungal fruiting structures, and fungal cultures. From three samples, DNA was extracted from tree tissue with symptoms resulting in the determination of $A$. gyrosa, $E$. glandulosa, and P. carpinea. DNA of C. pilosella, E. glandulosa, $R$. corticum, and $S$. hirsutum were isolated from the fruiting bodies. Non-culture-based method, DNA barcoding, was used to overcome the long turnaround times associated with fungal cultivation on the medium. The fungal cultures were prepared from the collected samples from which DNA samples failed to be isolated. Seven fungal species were determined from the culture medium (C. parasitica, E. nigrum, A. alternata, Cytospora sp., Cladosporium sp., P. glabrum, and A. pullulans). Cytospora sp. and Cladosporium sp. were determined on the genus level using ITS sequence because the BLAST report provided inconclusive data. Norphanphoun et al. (2017) combined morphological characteristics and multi-gene loci (ITS, large nuclear ribosomal RNA subunit sequence (LSU), RNA polymerase II subunit (RPB2), and $\alpha$-actin (ACT)) for determination and phylogenetic analysis of the Cytospora species. Furthermore, Tibpromma et al. (2019) reported usage of morphological examinations, culture characteristics and multi-gene sequence analysis (ITS, ACT, and translation elongation factor 1-alpha gene (TEF1)) for the determination of fungi isolates belonging to the genera Cladosporium. These scientific works suggested that the Cytospora $s p$. and Cladosporium sp. could be determined to species level performing multi-gene sequence analysis.

Regarding the phylum of the determined fungi, Ascomycota (11 species) predominated over Basidiomycota (2 species). Seven Ascomycota and two Basidiomycota were determined on the site of management unit East Psunj. Five Ascomycota were determined in Papuk Nature Park. The size of ITS sequence differs between Ascomycota and Basidiomycota having an average length of 500 and 600 base pairs (bp), respectively (Porter and Brian Golding 2011). In this research, the length of the ITS sequences of nine determined Ascomycota ranged from $515 \mathrm{bp}$ (A. pullulans and $E$. nigrum) to 584 bp (Cytospora sp.), and ITS2 sequence of three determined Ascomycota ranged from $248 \mathrm{bp}$ ( $C$. parasitica) to 326 bp (C. parasitica, hypovirulent). The ITS sequences of two Basidiomycota (E. glanduloza and S. hirzutum) were the same length of $557 \mathrm{bp}$. These sequences showed a high degree of identity of $97.21 \%-100 \%$ under $98 \%-100 \%$ coverage with the reference sequences in GenBank (NCBI). However, fungus A. girosa was determined based on GenBank similarities on the bases of ITS2 sequence showing $95.67 \%$ identity at $100 \%$ coverage, implicating the entire ITS sequence was needed for achieving a higher GenBank similarity score (Nilson et al., 2009). All sequences were submitted to GenBank (NCBI) (Table 1, 2) to serve for the identification of unknown fungal species and in the conservation of fungal diversity. 


\section{CONCLUSIONS}

In this study, plant materials with disease symptoms on forest trees and fungal fruiting bodies were sampled for determination in the area of management unit East Psunj and Papuk Nature Park. In total, 13 species of fungi were determined on the basis of disease symptoms, morphology of fruiting bodies and fungal cultures, and DNA barcoding. Every fungal sample was DNA barcoded, based on the ITS or ITS2 sequence. NCBI BLAST analyses demonstrated that ITS and ITS2 sequences of analysed fungi showed a high sequence identity of $97.21 \%-100 \%$ at $98 \%-100 \%$ coverage with reference sequences in GenBank (NCBI) except for $A$. gyrosa (95.65\% identity, $100 \%$ coverage). All sequences were submitted to GenBank (NCBI) and received the accession numbers (Tables 1, 2). In this research, DNA barcoding was accurate and a fast determination tool for the determination of fungi along with the disease symptoms and morphology of fungal cultures and fruiting structures.

\section{Author Contributions}

SNA, NC conceived, designed the research and carried out the field research, SNA, NC, MKV performed laboratory analysis and processed the data, NC, and SNA wrote the manuscript. All authors reviewed the final manuscript.

\section{Funding}

This research has been fully supported by the Croatian Science Foundation under the project IP-2018-07-1736 "Improving the services of Croatian forest ecosystems through the evaluation of fungal biodiversity based on DNA barcoding (ForFungiDNA)".

\section{Acknowledgments}

We would like to thank Edita Roca for technical support in laboratory analyses.

\section{Conflicts of Interest}

The authors declare no conflict of interest.

\section{REFERENCES}

Amid C, Alako BT, Balavenkataraman Kadhirvelu V, Burdett T, Burgin J, Fan J, Jayathilaka S, 2020. The European Nucleotide Archive in 2019. Nucleic Acids Res 48(D1): D70-D76. https://doi. org/10.1093/nar/gkz1063.

Blaalid R, Kumar S, Nilsson RH, Abarenkov K, Kirk PM, Kauserud H, 2013. ITS 1 versus ITS 2 as DNA metabarcodes for fungi. Mol Ecol Res 13(2): 218-224. https://doi.org/10.1111/1755-0998.12065.

Badotti F, de Oliveira FS, Garcia CF, Vaz ABM, Fonseca PLC, Nahum LA, Oliveira G, Góes-Neto A, 2017. Effectiveness of ITS and sub-regions as DNA barcode markers for the identification of Basidiomycota (Fungi). BMC Microbiol 17(1): 42. https://doi. org/10.1186/s12866-017-0958-x.

Brock PM, Döring H, Bidartondo MI, 2009. How to know unknown fungi: the role of a herbarium. New Phytol 181(3): 719-724. https://doi.org/10.1111/i.1469-8137.2008.02703x.

Butin HH, 1995. Tree diseases and disorders: causes, biology, and control in forest and amenity trees. Oxford University Press, UK, $264 \mathrm{p}$.

Casiraghi M, Labra M, Ferri E, Galimberti A, De Mattia F, 2010. DNA barcoding: a six-question tour to improve users' awareness about the method. Brief Bioinform 11(4): 440-453. https://doi. org $/ 10.1093 /$ bib/bbq003.

Ciardo DE, Schär G, Böttger EC, Altwegg M, Bosshard PP, 2006. Internal transcribed spacer sequencing versus biochemical profiling for identification of medically important yeasts. J Clin Microbiol 44(1): 77-84. https://doi.org/10.1128/JCM.44.1.7784.2006

Doyle J, Doyle JL, 1987. Genomic plant DNA preparation from fresh tissue-CTAB method. Phytochem Bull 19(11): 11-15.

E-Flora BC, 2013. Electronic atlas of the flora of British Columbia. Available online: https://ibis.geog.ubc.ca/biodiversity/eflora/ (10 June 2020).

EPPO, 2005. Cryphonectria parasitica. Bull EPPO 35: 295-298.

Federhen S, 2015. Type material in the NCBI Taxonomy Database. Nucleic Acids Res 43(D1): D1086-D1098. https://doi.org/10.1093/ nar/gku1127.

Hanlin RT, 1990. Illustrated genera of Ascomycetes. Aps Press.
Hebert PD, Cywinska A, Ball SL, Dewaard JR, 2003. Biological identifications through DNA barcodes. In: Proceedings of the Royal Society of London, Series B: Biological Sciences 270(1512): 313-321. https://doi.org/10.1098/rspb.2002.2218.

Hebert PD, Gregory TR 2005. The promise of DNA barcoding for taxonomy. Syst Biol 54(5): 852-859. https://doi. org/10.1080/10635150500354886.

Heiniger U, Rigling, D 1994. Biological control of chestnut blight in Europe. Annu Rev Phytopathol 32(1): 581-599. https://doi. org/10.1146/annurev.py.32.090194.003053.

Hofstetter V, Buyck B, Eyssartier G, Schnee S, Gindro K, 2019. The unbearable lightness of sequenced-based identification. Fungal Divers 96(1): 243-284. https://doi.org/10.1007/s13225-01900428-3.

Madden T, 2013. The BLAST sequence analysis tool. In The NCBI Handbook [Internet]. 2nd edition. National Centre for Biotechnology Information (US).

Martin KJ, Rygiewicz PT, 2005. Fungal-specific PCR primers developed for analysis of the ITS region of environmental DNA extracts. BMC Microbio/ 5(1): 1-11. https://doi.org/10.1186/1471-2180-5-28.

Naranjo-Ortiz, MA, Gabaldón T, 2019. Fungal evolution: major ecological adaptations and evolutionary transitions. Biol Rev 94(4): 1443-1476. https://doi.org/10.1111/brv.12510.

Nilsson RH, Ryberg M, Abarenkov K, Sjökvist E, Kristiansson E, 2009. The ITS region as a target for characterization of fungal communities using emerging sequencing technologies. FEMS Microbiol Lett 296(1): 97-101. https://doi.org/10.1111/j.15746968.2009.01618.x.

Novak Agbaba S, Ćelepirović N, Karija Vlahović MK, Liović B, 2015. Eutypella parasitica RW Davidson \& RC Lorenz sedam godina nakon prvog nalaza u Hrvatskoj. Šumar list 139(5-6): 263-270.

Norphanphoun C, Doilom M, Daranagama DA, Phookamsak R, Wen TC, Bulgakov TS, Hyde KD, 2017. Revisiting the genus Cytospora and allied species. Mycosphere 8(1): 51-97, https:// doi.org/10.5943/mycosphere/8/1/7.

Škvorc Ž, Franjić J, Krstonošić D, Sever K, Alešković I, 2011. Vegetacijska obilježja bukovih šuma Psunja, Papuka i Krndije. Croat J For Eng 32(1): 157-174. 
Porter TM, Brian Golding G, 2011. Are similarity-or phylogeny-based methods more appropriate for classifying internal transcribed spacer (ITS) metagenomic amplicons? New Phytol 192(3): 775782. https://doi.org/10.1111/i.1469-8137.2011.03838.x.

Prell HH, Day P, 2001. Plant-fungal pathogen interaction: a classical and molecular view. In: Plant-Fungal Pathogen Interaction. Springer, Berlin, Heidelberg, Germany. https://doi. org/10.1007/978-3-662-04412-4 12.

Promputtha I, Lumyong S, Dhanasekaran V, McKenzie EHC, Hyde $K D$, Jeewon $R, 2007$. A phylogenetic evaluation of whether endophytes become saprotrophs at host senescence. Microb Ecol 53(4); 579-590. https://doi.org/10.1007/s00248-006-9117-x.

Raja HA, Miller AN, Pearce CJ, Oberlies NH, 2017. Fungal identification using molecular tools: a primer for the natural products research community. J Nat Prod 80(3): 756-770. https://doi.org/10.1021/ acs.jnatprod.6b01085.

Robin C, Henagar U, 2001. Chestnut blight in Europe: diversity of Cryphonectria parasitica, hypovirulence and biocontrol. Forest Snow and Landscape Research 76(3): 361-367.

Seifert KA, 2009. Progress towards DNA barcoding of fungi. Mol Ecol Resour 9: 83-89. https://doi.org/10.1111/j.17550998.2009.02635.x.

Schoch CL, Seifert KA, Huhndorf S, Robert V, Spouge JL, Levesque CA, Chen W, Fungal Barcoding Consortium, 2012. Nuclear ribosomal internal transcribed spacer (ITS) region as a universal DNA barcode marker for Fungi. Proceedings of the National Academy of Sciences 109(16): 6241-6246. https://doi.org/10.1073/ pnas.1117018109.

Shi XX, Qiu HP, Wang JY, Zhang Z, Wang YL, Sun GC, 2019. A handy method to remove bacterial contamination from fungal cultures. PLoS One 6: 14(11). https://doi.org/10.1371/journal. pone. 0224635 .

Sieber T, Hugentobler C, 1987. Endophytic fungi in leaves and twigs of healthy and diseased beech trees (Fagus sylvatica L.). European Journal of Forest Pathology 17(7): 411-425.
Sinclair JB, Dhingra OD, 1995. Basic plant pathology methods. CRC press, $448 \mathrm{p}$.

Sinclair JB, Cerkauskas RF, 1996. Latent infection vs. endophytic colonization by fungi. In: Redlin SC, Carris LM (eds) Endophytic fungi in grasses and woody plants: systematics, ecology, and evolution. APS Press, UK, 3-30.

Stone JK, Bacon CW, White JF, 2000. An overview of endophytic microbes: Endophytism defined. In: Bacon CW, White JF (eds) Microbial Endophytes. Marcel Dekker, New York, USA,: pp. 3-29.

Tibpromma S, Mortimer PE, Karunarathna SC, Zhan F, Xu J, Promputtha I, Yan K, 2019. Morphology and Multi-Gene Phylogeny Reveal Pestalotiopsis pinicola sp. nov. and a New Host Record of Cladosporium anthropophilum from Edible Pine (Pinus armandii) Seeds in Yunnan Province, China. Pathogens 8(4): 285. https://doi.org/10.3390/pathogens8040285.

Unterseher M, Schnittler M, 2010. Species richness analysis and ITS rDNA phylogeny revealed the majority of cultivable foliar endophytes from beech (Fagus sylvatica). Fungal Ecol 3(4): 366378. https://doi.org/10.1111/j.1365-294X.2010.04948.x.

Yang RH, Su JH, Shang JJ, Wu YY, Li Y, Bao DP, Yao YJ, 2018. Evaluation of the ribosomal DNA internal transcribed spacer (ITS), specifically ITS1 and ITS2, for the analysis of fungal diversity by deep sequencing. PloS One 13(10). https://doi.org/10.1371/ journal.pone.0206428.

White TJ, Bruns T, Lee S, Taylor JW, 1990. Amplification and direct sequencing of fungal ribosomal RNA genes for phylogenetics. In: Innis MA, Gelfand DH, Sninsky JJ, White TJ (eds) PCR Protocols: A Guide to Methods and Applications. Academic Press Inc., New York, USA, pp. 315-322.

Xu J, 2016. Fungal DNA barcoding. Genome 59(11): 913-932. https:// doi.org/10.1139/gen-2016-0046.

Zúbrik M, Kunca A, Novotný J, 2008. Hmyz a huby: atlas poškodení lesných drevín. Národné lesnícke centrum-Lesnícky výskumný ústav Zvolen, Zvolen, Slovak Republic. 